\title{
Enzymatic hydrolysis of coconut oil using free and immobilized porcine pancreas lipases
}

- Nguyen Thi Ai Van ${ }^{1}$

- Phan Ngoc Hoa ${ }^{2}$

- Tran Bich Lam ${ }^{2}$

- Chau Tran Diem Ai ${ }^{2}$

${ }^{1}$ Industrial University of HCMC Young Researchers Association

${ }^{2}$ Ho Chi Minh city University of Technology, VNU-HCM

(Manuscript Received on November 24th, 2015, Manuscript Revised May 11th, 2016)

\begin{abstract}
The aim of this study is to evaluate the effect of some factors on the hydrolysis of coconut oil $(\mathrm{CO})$ in the present of two kind of enzymes, the free lipases and immobilized lipases porcine pancreas. The activities of these two lipases under the optimal hydrolysis conditions was determined.

The effects of factors on hydrolysis degree of coconut oil was investigated: the ratio of enzyme to substrate, the $\mathrm{pH}$ condition, and the temperature. The best conditions for the high hydrolysis degree in case of using lipase from porcine pancreas ascatalyst included: the ratio

of the enzyme to substrate of $90(\mathrm{U} / \mathrm{mL})$, and the $p H$ condition of 8.5 at the temperature of $40^{\circ} \mathrm{C}$. The best reaction condition the case of using immobilized porcine pancreas lipase as the catalyst was determined, including: the ratio enzyme to substrate of $393 \mathrm{U} / \mathrm{g}$, the $\mathrm{pH}$ condition of 7.5 and the temperature of $35^{\circ} \mathrm{C}$. The hydrolysis degree of CO by immobilized porcine pancreas lipase was increased slower than free lipase at the first time. The highest hydrolysis degree achieved with immobilized porcine pancreas and free porcine pancreas lipase was $72.26 \%$ and $68.61 \%$, respectively.
\end{abstract}

Keywords: coconut oil, hydrolysis, immobilized porcine pancreas lipase, free porcine pancreas lipase

\section{INTRODUCTION}

Coconut oil $(\mathrm{CO})$ is a popular agricultural product in Vietnam as well as in other tropical countries such as Philippines, Thailand, India, Indonesia, Sri Lanka, Malaysia and New Guinea.
$\mathrm{CO}$ is composed of short and medium chain fatty acids. Coconut oil has been used for health promotion, aliment prevention and for medication [6]. Hydrolysis products from

\section{Trang 70}


coconut oil such as: glycerol and saturated fatty acids are mainly used in food industry, pharmaceutical and cosmetics [5].

Depending on the hydrolysis conditions, the hydrolysis products have different features. In which, there are some compounds having bioactive. Lauric acid is a medium chain fatty acid with high antibacterial characteristic [4]. The applications of lauric acid on food industry has been reported by researchers and nutrition experts $[1,3]$.

The products from the enzymatic hydrolysis of coconut oil have higher bioactive activity than the hydrolysis products from chemical hydrolysis [2]. Enzymatic hydrolysis is an advantageous method because it can be performed at lower temperature, leading to products with fewer side product. However, lipases as well as other enzymes has low thermal stability and high cost, which limits its potential applications in industrial hydrolytic reactions. To increase the stable and lower the cost of lipase, using of immobilized lipase on several supports has been reported for oil hydrolysis reactions [7]. The aim of this study was to compare the effect of lipases from porcine pancreas and immobilized porcine pancreas on the hydrolysis of coconut oil

\section{MATERIALS AND METHODS}

Refined coconut oil used in this study was purchased from Tin Vui company, Vietnam. Lipase from porcine pancreas (type II, L3126, 60 U/mg) were supplied by Sigma-Aldrich Co. (USA). Carriers hydrotalcite was prepared at the Institute of Chemical Technology - Vietnam Academy of Science and Technology. Acasia gum (Instantgum ${ }^{\mathrm{TM}} \mathrm{BA}$ ) (Nexira, France) was purchased from Asian Shine company. Reagents used in this study were $\mathrm{NaOH}$ solution of $0.1 \mathrm{M}$,
$\mathrm{KOH}$ solution of $0.1 \mathrm{M}, \mathrm{H}_{3} \mathrm{PO}_{4} \quad 85 \%$, phenolphthalein $1 \%$ in ethanol as the $\mathrm{pH}$ indicator, $\mathrm{H}_{2} \mathrm{SO}_{4}$ solution of $0.1 \mathrm{~N}$, borate buffer. These reagents were at analytical standard and these solutions were prepared as procedures described in Vietnamese standard No 4320-86.

\subsection{Hydrolysis of coconut oil using free porcine pancreas lipase (PPL)}

Coconut oil emulsion was prepared in borate buffer, $\mathrm{pH}$ from 7.5 to 9.0

A mixture of acasia gum $(3 \mathrm{~g} / 100 \mathrm{ml})$ and 30 $\mathrm{ml}$ of $\mathrm{CO}$ and buffer solution (the volume of buffer were changed respectively 15, 30, 60, 90 $\mathrm{ml}$ ) were placed in an $250 \mathrm{ml}$-Erlenmeyer flask. Emulsifying the mixture was carried out using an homogenizer in 20 minutes. To start the reaction, $1 \%$ solution of lipase porcine pancreas in borate buffer were added slowly. This mixture was stirred using magnetic stirrer for 10 minutes. The hydrolysis reaction was performed in an appropriate duration. The range of reaction duration was 5 hours at temperature of (30 $60^{\circ} \mathrm{C}$ ). The mixture was shaken for 10 minutes in every one hour. To stop the reaction, $3 \mathrm{ml}$ of ethanol $99.5 \%$ were added in the reaction mixture. The effect of tree factors including the $\mathrm{pH}$ condition, the temperature and the concentration of enzyme in the $\mathrm{CO}$ hydrolysis were studied. From the output data, the change of hydrolysis degree versus the reaction time was determined.

Hydrolysis rate was calculated as the amount in milliliter of $\mathrm{KOH} 0.1 \mathrm{M}$ needed per a minute:

Hydrolysis rate,

$r(\mu \mathrm{mol} /$ minute $)=\frac{(a-b) * 0.1 * 1.000 .000}{1000 * 60}$ 
a: The amount of $\mathrm{ml} \mathrm{KOH} 0.1 \mathrm{M}$ in sample

b: The amount of $\mathrm{ml} \mathrm{KOH} 0.1 \mathrm{M}$ in blank

Hydrolysis degree (DH)\%

$$
\mathrm{DH}(\%)=\frac{(a-b) \times 0.1 \times \bar{M}}{m \times 10}
$$

a: The amount of $\mathrm{ml} \mathrm{KOH} 0.1 \mathrm{M}$ insample

b: The amount of $\mathrm{ml} \mathrm{KOH} 0.1 \mathrm{M}$ in blank

$\bar{M}$ :The average molecular weight of fatty acids in coconut oil

$\mathrm{m}$ : The volume of coconut oil was used $(\mathrm{g})$.

\subsection{Hydrolysis of $\mathrm{CO}$ using immobilized} porcine pancreas lipase on HT ace 0.15M- 500

\subsubsection{Lipase immobilization}

The porcine pancreas lipase was immobilized on the hydrotalcite carrier by coprecipitation method using two kinds of salt $\mathrm{Al}\left(\mathrm{NO}_{3}\right)_{3}$ and $\mathrm{Mg}\left(\mathrm{NO}_{3}\right)_{2}$ with the ratio of $\mathrm{Mg} / \mathrm{Al}$ was $2 / 1$ and intermixing acetate ion concentration of $0.15 \mathrm{M}$. Then the hydrotalcite was baked at $500^{\circ} \mathrm{C}$ for 2 hours. The lipase was mixed with hydrotalcite carrier in the borate buffer solution at $\mathrm{pH}$ 7.5. The mixture was stirred at the temperature of $32^{\circ} \mathrm{C}$ and the speed of 300rpm in 5 hours. After that, the immobilized porcine pancreas lipase was separated from the solution by a centrifuge. The activity of immobilized enzyme was 1965.4U/ g.

\subsubsection{Hydrolysis of coconut oil with immobilized lipase:}

Hydrolysis reaction was carried out the same way with free lipase. To stop the reaction, immobilized enzyme was centrifuged at $6,000 \mathrm{rpm}$ for 10 minutes at the room temperature in order to separate the solution and the immobilized enzyme. Immobilized PPL was rinsed with borate buffer and reused.

\subsection{Analytical methods}

Acid, peroxide and iodine value of coconut oil were determined according to Vietnamese standard No 6127:2010; 6121:2010; 6122:2010

Composition and concentration of fatty acid were determined by gas chromatography according to AOAC standard No 969.33. A GC 2010 gas chromatograph (Shimadzu, Japan) equipped with FID detector was used. Separation was carried out in a TR-Fame column with dimension of $60 \mathrm{mx} 0.25 \mathrm{~mm}$ i.d.x $0.25 \mu \mathrm{m}$. The oven temperature profile was: $150^{\circ} \mathrm{C}(3 \mathrm{~min})$, $20^{\circ} \mathrm{C} / \mathrm{min}$ to $220^{\circ} \mathrm{C}(7 \mathrm{~min}), 5^{\circ} \mathrm{C} / \mathrm{min}$ to $240^{\circ} \mathrm{C}$ (5min). Helium was used as a gas carrier. Samples and standard were injected at the volume of $1 \mu 1$.

Analysis of variance (ANOVA) with Statgraphic Centurion XV.I software was employed to analyze the differences among group means $(\mathrm{P} \leq 0.05)$

\section{RESULTS AND DISCUSSION}

\subsection{Characteristics of coconut oil}

Total lipid content in coconut oil was $99.25 \%$ in which free fatty acids was $0.06 \%$. Acid, iodine, and peroxide value was $0.13 \mathrm{mg}$ $\mathrm{KOH} / \mathrm{g}, \quad 9.85 \mathrm{~g} / 100 \mathrm{~g}$, and $2.0 \mathrm{meq} / \mathrm{kg}$, respectively.

Table 1 showed that the major fatty acid in coconut oil was acid lauric (49.2\%), a kind of saturated fatty acid. From the content of fatty acids, average molecular weight of coconut fatty acids was $206.99 \mathrm{~g}$.

\section{Trang 72}


Table 1. Composition and content of fatty acids in coconut oil, \%

\begin{tabular}{|l|l|c|}
\hline \multicolumn{1}{|c|}{ Fatty Acid } & \multicolumn{1}{|c|}{$\begin{array}{c}\text { Common } \\
\text { name }\end{array}$} & $\begin{array}{c}\text { Content } \\
(\%)\end{array}$ \\
\hline Octanoic acid, C8:0 & Caprylic acid & 10,9 \\
\hline $\begin{array}{l}\text { Decanoic acid, } \\
\text { C10:0 }\end{array}$ & Capric acid & 7,56 \\
\hline $\begin{array}{l}\text { Dodecanoic acid, } \\
\text { C12:0 }\end{array}$ & Lauric acid & 49,2 \\
\hline $\begin{array}{l}\text { Tetradecanoic acid, } \\
\text { C14:0 }\end{array}$ & Myristic acid & 17,4 \\
\hline $\begin{array}{l}\text { Hexadecanoic acid, } \\
\text { C16:0 }\end{array}$ & Palmitic acid & 7,29 \\
\hline $\begin{array}{l}\text { Octadecanoic acid, } \\
\text { C18:0 }\end{array}$ & Steric acid & 1,98 \\
\hline $\begin{array}{l}\text { Cis-9-Octadecenoic } \\
\text { acid, C18:1 }\end{array}$ & Oleic acid & 4,38 \\
\hline $\begin{array}{l}\text { Cis- } \\
\text { Octadecadienoic } \\
\text { acid, C18:2 }\end{array}$ & 1,28 \\
\hline
\end{tabular}

\subsection{Investigation of oil hydrolysis conditions} using free PPL

a) Enzyme/substrate

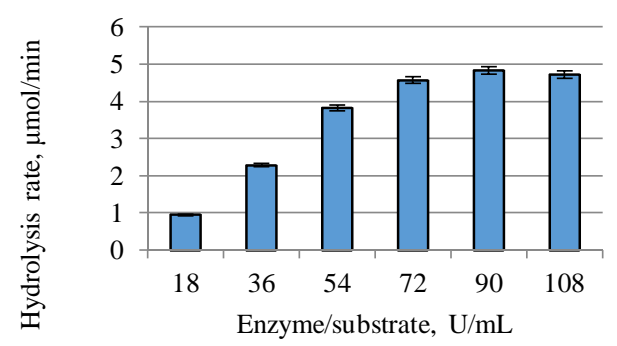

b) $\mathrm{pH}$

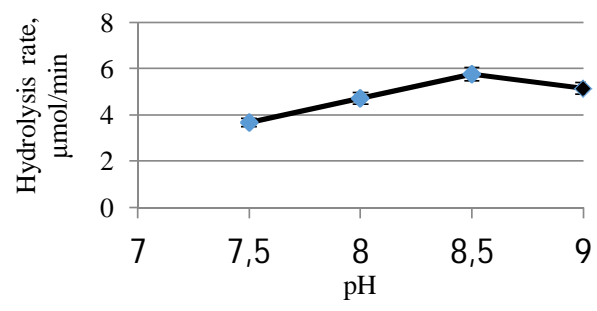

c) Temperature

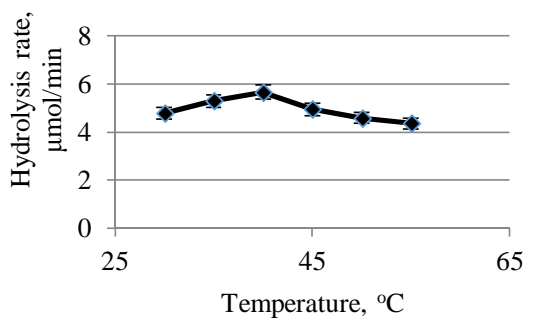

Figure 1. The ratio of enzyme/substrate (a), pH (b) and temperature (c) effect on hydrolysis of coconut oil by free PPL

The effect of factors on the hydrolysis coconut oil using PPL as a catalyst were shown in Figure 1. Accordingly, the appropriate parameters were selected as the ratio of the enzyme to the substrate of $90 \mathrm{U} / \mathrm{mL}$, the suitable $\mathrm{pH}$ condition was 8.5 and the temperature was $40^{\circ} \mathrm{C}$.

\subsection{Investigation of oil hydrolysis conditions} using PPL immobilized on HT ace- 0.15M 500

a) Enzyme/substrate

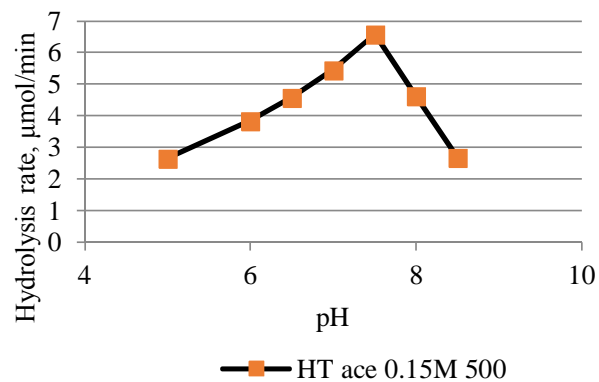


b) $\mathrm{pH}$

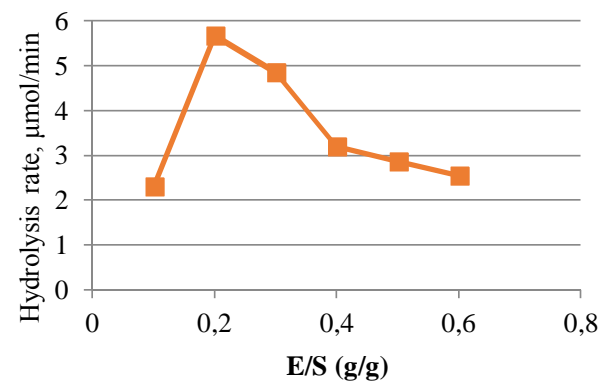

$\longrightarrow$ HT ace $0.15 \mathrm{M} 500$

c) Temperature

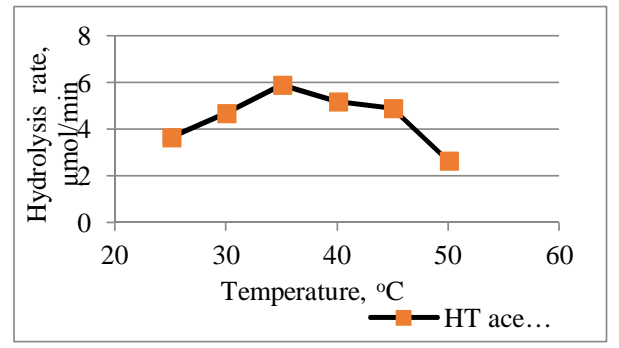

Figure 2. The ratio of enzyme/substrate (a), $\mathrm{pH}$ (b) and temperature (c) effect on hydrolysis of coconut oil by HT ace $0.15 \mathrm{M} 500$

The effect of factors on the hydrolysis coconut oil using immobilized LPP as a catalyst were shown in Figure 2. The results showed that appropriate ratio of the immobilized enzyme to the substrate of $0.2 \mathrm{~g} / \mathrm{g}(392 \mathrm{U} / \mathrm{g})$, the suitable $\mathrm{pH}$ condition was 7.5 and the temperature of $35^{\circ} \mathrm{C}$.

As well as free enzyme, immobilized enzyme has a $\mathrm{pH}$ value appropriate for the reaction. However, optimum $\mathrm{pH}$ for immobilized lipase was 7.5 while the free enzyme has optimum $\mathrm{pH}$ was 8.5 . Thus, it can be said that the support has a $\mathrm{pH}$ condition affected on enzyme activity. The effects of the support on optimum $\mathrm{pH}$ of the enzyme was studied by Lee Dong-Geun et al (2009) with the enzyme pocine pancreas lipase immobilized on hydrophobic nano-sized magnetic particles, when examining the influence of $\mathrm{pH}$ on the activity of the free and immobilized lipase enzyme, resulting in optimum $\mathrm{pH}$ of 6.7 for PPL free while immobilized was 7.7 [8]. In our case, the optimum of $\mathrm{pH}$ condition of immobilized lipase was moved to rather acidify area. Thus, under the influence of the support, the nature of the enzyme also varies as the optimal parameters change as well.

3.4 Hydrolysis of coconut oil with free PPL and immobilized PPL on HT ace 0.15M -500

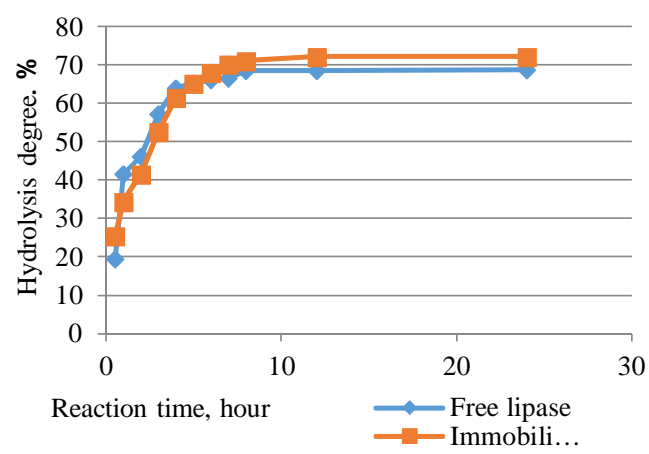

Figure 3. Hydrolysis degree (\%) of $\mathrm{CO}$ according to the reaction time of free and immobilized PPL

Figure 3 shown that, the hydrolysis degree of CO by free PPL was higher than the one from immobilized at the first time of the reaction. However, after 8 hours of hydrolysis, the hydrolysis degree of CO by PPL was increased slowly and reached to the highest of $68.49 \%$ while the highest hydrolysis degree of the HT ace $0.15 \mathrm{M}-500$ was $72.12 \%$ after 12 hours. And after 24 hours the hydrolysis degree of these two enzyme were slightly reduced.

3.5 Reuse times of the immobilized lipase

\section{Trang74}




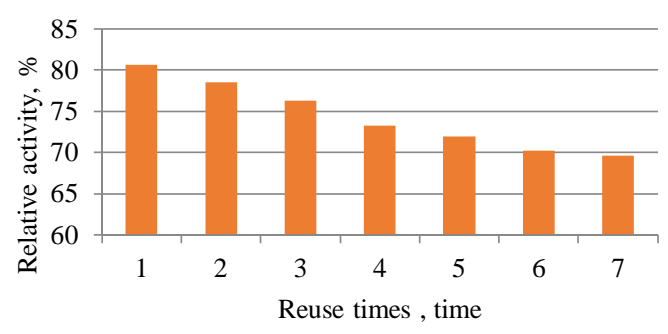

Figure 4. The reusability of immobilized lipase on the HT ace $0.15 \mathrm{M}-500$

Reusability is a major advantage of using immobilized lipase. The activity of immobilized porcine pancreas lipase maintained $69.6 \%$ after being reused 7 times. This result can be compared with some other authors, Knezevic et al., immobilized lipase from Candida cylindracea on zeolite to hydrolyze palm oil, after 7 times the reused relative activity was $13.2 \%$ [9], Li et al., used lipase from Candida rugosa immobilized on polyacrylonitril to hydrolyze soybean oil, after 7 times of use, the activity was $62.7 \%$ [7]

\section{CONCLUSION}

The hydrolysis of coconut oil by PPL and HT ace $0.15 \mathrm{M} 500$ had the appropriate temperature were $40^{\circ} \mathrm{C}$ and $35^{\circ} \mathrm{C}$, respectively. The $\mathrm{pH}$ condition for the PPL was more alkaline (8.5) than the immobilized enzyme, which was 7.5. The ratio of PPL to substrate was $90 \mathrm{U} / \mathrm{mL}$ while the ratio of immobilized lipase to substrate was $385 \mathrm{U} / \mathrm{g}$. The hydrolysis degree of $\mathrm{CO}$ by the free PPL was higher than that by the immobilized lipase around five hours at the first time of the reaction. The hydrolysis degree of $\mathrm{CO}$ by immobilized lipase was slightly raised to $72.12 \%$ after 12 hours. The activity of immobilized porcine pancreas lipase maintained $69.6 \%$ after being reused 7 times.

Acknowledgment: This research is funded by Ho Chi Minh city University of Technology Vietnam National University under grant number TNCS-KTHH-2015-26 


\section{Thủy phân dầu dừa bằng enzyme porcine pancreas tự do và cố định}

- Nguyễn Thị Ái Vân ${ }^{1}$

- Phan Ngọc Hòa ${ }^{2}$

- Trần Bích Lam ${ }^{2}$

- Châu Trần Diễm Ái ${ }^{2}$

${ }^{1}$ Câu lạc bộ nghiên cứu khoa học trẻ, Trường Đại Học Công Nghiệp Tp.HCM

${ }^{2}$ Trường Đại Học Bách Khoa, ĐHQG-HCM

\section{TÓM TẮT}

Mục đỉch của nghiên cứu này là đánh giá ảnh huởng của một số yếu tố đến quá trình thủy phân dầu dùa bằng hai loại enzyme porcine pancreas tụ do và cố định, đồng thời xác định đurọc điều kiện thủy phân tối un của hai loại enzyme này.

Một số yếu tố ảnh huởng đến quá trình thủy phân dầu dùa bởi hai loại enzyme porcine pancreas tư do và cố định được khảo sát là: tỉ lệ enzyme đối với cơ chất, điều kiện $p H$ và nhiệt độ. Điều kiện thủy phân dầu dìa tối unu với xúc tác

enzyme porcine pancreas tư do là: tỉ lẹ enzyme/ co chất: $90(\mathrm{U} / \mathrm{mL}), p H=8.5$, nhiệt dộ $40^{\circ} \mathrm{C}$. Trong khi đó, điều kiện thủy phân dầu dùa tối uu với xúc tác là porcine pancreas cố định trên chất mang hydrotalcite là: tỉ lẹ enzymel co chất: $393 \mathrm{U} / \mathrm{g}, \mathrm{pH}=7.5$ và nhiệt độ $35^{\circ} \mathrm{C}$. Mưc độ thủy phân dầu dùa bằng enzyme cố định ở giai đoạn đầu tăng chậm hơn so với enzyme porcine pancreas tư do. Hiệu suất thủy phân dầu dù̀ cao nhất đạt được với enzyme porcine pancreas cố định và tụ do lần lươt là: $72.26 \%$ và $68.61 \%$

Tù khóa: dầu dùa, enzyme porcine pancreas cố định, enzyme porcine pancreas tụ do, thủy phân.

\section{REFERENCES}

[1]. Dayrit F. M. -The Properties of Lauric Acid and Their Significance in Coconut Oil Journal of the American Oil Chemists' Society, vol. 92 (2015) 1-15.

[2]. Silalahi J., Tripermata Y., and Delux Putra E.- Antibacterial activity of hydrolyzed virgin coconut oil -Asian Journal of Pharmaceutical and Clinnical Research, vol. $7(02 / 2014)$

[3]. Elysa, Harahap U., and Silalahi J. Antibacterial activity of enzymatic hydrolysis of virgin coconut oil against Samonella-International Journal of PharmTech Research, vol. 6 (2014) 589599

[4]. Nandi S., Gangopadhyay S., and Ghosh S.Production of medium chain glycerides from coconut and palm kernel fatty acid distillates by lipase-catalyzed reactions -

\section{Trang 76}


Enzyme and Microbial Technology, vol. 36 (2005) 725-728.

[5]. Enig M. G. - Health and nutritional benefits from coconut oil and it advantages over competing oils - Indian Coconut Journal (2010) 9-15

[6]. Dayrit C.S. - Coconut oil in: Health and Disease: Its And Monolaurin's Potential As Cure For HIV/AIDS - Cocotech Meeting Chennai, 2000, XXXVII

[7]. Li S.F, Wu W.T. - Lipase- immobilized electrospun PAN nanofibrous membranes for soybean oil hydrolysis- Biochemical engineering journal 45(2009) 48-53

[8]. Lee D. et al - Immobilization of lipase on hydrophobic nano-sized magnetic particles - Journal of Molecular Catalysis B: Enzymeatic 57(2009) 62-66

[9]. Knezevic Z., Mojovic L. Adnadjevic B.Palm oil hydrolysis by lipase from Candida cylindracea immobilized on zeolite type YEnzyme Microb. Technology 22 (1998) 275-280 